\title{
Overseas doctors: working, training, and failing in Britain
}

\author{
RICHARD SMITH
}

The problems of overseas doctors in Britain and the problems created for the National Health Service by its heavy dependence on them have long been recognised ${ }^{1}{ }^{2}$ but have not been properly studied until recently. The NHS has needed overseas doctors badly, and in an unplanned way they have been allowed into Britain to work. They have filled the gaps created by poor manpower planning and allowed the continuation of a system that has two juniors to every one consultant. Many found the training they sought, but others drifted into unsuitable jobs in peripheral hospitals and received little useful training.

The uneasy relationship between the NHS and overseas doctors was discussed by both the Royal Commission on Medical Education (the Todd Commission) 1 in 1968 and the Committee of Inquiry into the Regulation of the Medical Profession (the Merrison Committee), which was set up in 1972 and reported in $1975 .{ }^{3}$ The Todd Commission regretted that there was "no reliable information about the number, origins, and length of stay of unsponsored overseas postgraduate medical students in Britain," but hoped that the proposals it made would "end the present haphazard nature of the training received by many young doctors from overseas." Sadly, 13 years later, things are probably worse rather than better. The Merrison Committee was concerned less with the problems of overseas doctors and more with suggestions that the standards of overseas doctors were lower than those of British doctors. It had only flimsy evidence-much of it subjective-to consider, but it did recommend changes in the system of registration and the introduction of a test for some overseas doctors.

Since the Commission reported the number of overseas doctors in the NHS has risen, and-in response to both the Merrison Committee and the Royal Commission on the NHS ${ }^{4}-$ a large study of overseas doctors has been carried out. This was done by David Smith of the Policy Studies Institute and answered such questions as: where are overseas doctors working? what jobs are they doing? what are their aims and are they fulfilling them ? and what are their problems $?^{5}$ This article will consider similar questions, drawing heavily on Smith's study.

It must be remembered, however, that Smith's was a one-off study of nearly 2000 doctors carried out between September 1977 and February 1978. The results therefore over-represent the problems and opinions of overseas doctors who stay longer, and, as the study shows, those who stay longer tend to be the ones who do worst. No data are perfect, but these are the best we have.

\section{Where are the overseas doctors and what jobs do they do?}

Department of Health and Social Security figures show that at least $20 \%$ of the hospital doctors in every region in England in 1977 qualified overseas. The South-western Region had the lowest proportion $(20 \%)$ and the North-western Region had the highest $(40 \%)$. Overseas qualified general practitioners were less evenly spread, however, as Smith's study showed (table I): only 3\% of general practitioners in Wessex and South-western Regions qualified overseas as opposed to $27 \%$ in North-west and North-east Thames. Overseas doctors were concentrated in cities: $23 \%$ of general practitioners in conurbations qualified overseas as opposed to $11 \%$ elsewhere. A more striking difference emerged when Smith analysed doctors working in a teaching

British Medical Journal, London WC1H 9JR

RICHARD SMITH, BSC, MB, assistant editor district-that is, districts that include undergraduate teaching hospitals. About $46 \%$ of British graduates and $47 \%$ of graduates from white Anglophone countries who were doing hospital jobs worked in teaching districts, whereas only $17 \%$ of graduates from the Indian subcontinent and $18 \%$ of Arabian or Iranian graduates did so.

About two-thirds of the 18000 overseas doctors in Britain in 1978 worked in hospital, and most were junior doctors. About $45 \%$ of British graduates and $33 \%$ of white Anglophone doctors were consultants, but only $9 \%$ of doctors from the Indian subcontinent were. About $42 \%$ of overseas qualified doctors were junior house officers and $31 \%$ were registrars. Table II shows the specialties in which the British and overseasqualified doctors worked. Nobody will be surprised that overseas doctors were over-represented in geriatrics, anaesthetics, and psychiatry and under-represented in general medicine.

TABLE I-Percentage of general practitioners who qualified overseas in pairs of regions

\begin{tabular}{|c|c|}
\hline Region & $\begin{array}{c}\text { Percentage of } \\
\text { overseas-qualified } \\
\text { general } \\
\text { practitioners }\end{array}$ \\
\hline $\begin{array}{l}\text { Northern and Yorkshire } \\
\text { Trent and East Anglia } \\
\text { North-west and North-east Thames } \\
\text { South-west and South-east Thames } \\
\text { Wessex and South Western .. } \\
\text { Oxford and West Midlands .. } \\
\text { Mersey and North Western .. }\end{array}$ & $\begin{array}{r}12 \\
10 \\
27 \\
13 \\
3 \\
22 \\
19\end{array}$ \\
\hline
\end{tabular}

TABLE II-Specialty of British and overseas-qualified hospital doctors

\begin{tabular}{|c|c|c|}
\hline Specialty & $\begin{array}{c}\text { British or Irish } \\
\text { graduates working } \\
\text { in the specialty } \\
(\%)\end{array}$ & $\begin{array}{l}\text { Overseas graduates } \\
\text { working in the } \\
\text { specialty } \\
(\%)\end{array}$ \\
\hline $\begin{array}{l}\text { Paediatrics } \ldots \\
\text { Geriatrics } \ldots \text {. } \\
\text { General medicine } \ldots \\
\text { Other medical specialties }\end{array}$ & $\begin{array}{r}5 \\
2 \\
14 \\
6\end{array}$ & $\begin{array}{l}3 \\
9 \\
7 \\
4\end{array}$ \\
\hline $\begin{array}{l}\text { Orthopaedics } \\
\text { General surgery } \\
\text { Other surgical specialties }\end{array}$ & $\begin{array}{r}5 \\
11 \\
5\end{array}$ & $\begin{array}{l}9 \\
9 \\
8\end{array}$ \\
\hline $\begin{array}{l}\text { Anaesthetics } \\
\text { Radiology or radiotherapy } \\
\text { Gynaecology and obstetrics } \\
\text { All pathology specialties . } \\
\text { All psychiatric specialties. } \\
\text { Accident and emergency } \\
\text { Other specialties } \\
\text { Not stated .. }\end{array}$ & $\begin{array}{l}9 \\
7 \\
8 \\
8 \\
8 \\
3 \\
6 \\
3\end{array}$ & $\begin{array}{r}12 \\
4 \\
9 \\
4 \\
10 \\
3 \\
5 \\
4\end{array}$ \\
\hline
\end{tabular}

These figures support the conventional wisdom that overseas doctors are doing mostly junior hospital jobs in peripheral hospitals in unpopular specialties. They are supporting the pyramidal structure of the hospital health service (which has roughly one consultant to two juniors) by doing the junior jobs and then disappearing, allowing their British colleagues to take the consultant jobs. This might be seen as satisfactory for the health authorities as it allows the perpetuation of a relatively cheap hospital service in which most of the work is done by junior doctors. But is it desirable to perpetuate this system? Also is it right that overseas doctors should be concentrated in those specialties-psychiatry and geriatrics-where language and intimate understanding of local culture are most important. 


\section{Aims and training}

Most overseas doctors ( $85 \%$ ) said that their main reason for coming to Britain was to further their training. Most $(87 \%)$ wanted to acquire postgraduate qualifications, particularly membership or fellowship of one of the British royal colleges. In contrast to British graduates, of whom only $42 \%$ definitely wanted to become specialists at the time they passed their first degree, $89 \%$ of the overseas doctors wanted to become specialists. Presumably it is those who want to specialise who take the trouble to come to Britain. Table III shows the specialties in which they wanted to work compared with the actual distribution of overseas graduates in the various specialties. Not surprisingly the preferred special+ies were general medicine, general surgery, obstetrics and gynaecology, and paediatrics.

Many of the overseas doctors did not acquire the postgraduate qualifications they wanted, did not succeed in specialising, and were not working in the specialty of their choice. Smith has no doubt that many do quickly acquire the training they want and then return home, but some do not. Of those who had been in Britain nine years or more, $46 \%$ had passed the MRCP or fellowship and $8 \%$ had their part I only. About $35 \%$ of those who had been here for five to eight years had their MRCP or fellowship. The study showed also that $78 \%$ of the overseas doctors (excluding white Anglophones) who were general practitioners had originally wanted to be specialists-as opposed to $24 \%$ of British graduates. Table III confirms that many overseas doctors working in hospital were not in the specialty of their first choice. This discrepancy also applied to British graduates but was less obvious.

Overseas doctors, particularly those who are not sponsored and are not white Anglophones, have great difficulty in getting a succession of good training jobs. They do not have the connections and the references, and perhaps they are discriminated against (a point I will return to). About $33 \%$ of those who were not white Anglophones expressed disappointment with job opportunities and $24 \%$ with opportunities for study and teaching. This is a much higher proportion than among British and overseas white Anglophone doctors (table IV). Also $40 \%$ of doctors from the Indian subcontinent and Arab countries had progressed more slowly than they expected in their career as opposed to $22 \%$ of British graduates and $16 \%$ of white Anglophone graduates. This may, of course, reflect unrealistic expectations.

TABLE III-Preferred specialty compared with actual distribution of hospital posts for overseas-qualified doctors

\begin{tabular}{|c|c|c|}
\hline Specialty & $\begin{array}{c}\text { Preferred specialty } \\
(\%)\end{array}$ & $\begin{array}{c}\text { Actual specialty } \\
(\%)\end{array}$ \\
\hline $\begin{array}{l}\text { Paediatrics } . . \\
\text { Geriatrics } \\
\text { General medicine } \ldots \\
\text { Other medical specialties }\end{array}$ & $\begin{array}{r}7 \\
0 \\
18 \\
6\end{array}$ & $\begin{array}{l}3 \\
9 \\
7 \\
4\end{array}$ \\
\hline $\begin{array}{l}\text { General surgery } \\
\text { Other surgical specialties }\end{array}$ & $\begin{array}{r}28 \\
8\end{array}$ & $\begin{array}{r}9 \\
17\end{array}$ \\
\hline $\begin{array}{l}\text { Anaesthetics } \\
\text { Radiology or radiotherapy. } \\
\text { Gynaecology and obstetric } \\
\text { Pathology specialties } \\
\text { Psychiatry specialties } \\
\text { Accident and emergency } \\
\text { Other specialties } \quad . \\
\text { Not stated .. }\end{array}$ & $\begin{array}{r}6 \\
2 \\
15 \\
2 \\
4 \\
0 \\
4\end{array}$ & $\begin{array}{r}12 \\
4 \\
9 \\
4 \\
10 \\
3 \\
5 \\
4\end{array}$ \\
\hline
\end{tabular}

\section{Do overseas doctors do badly because of discrimination?}

For philosophical, ethical, methodological, and legal reasons it is difficult-if not impossible-to answer the question whether overseas doctors are discriminated against. Black and coloured overseas doctors certainly do worse than British and overseas white doctors in finding good jobs. (In Smith's study 39\% of coloured overseas doctors had made more than seven applications to find their present job as opposed to $8 \%$ of British graduates
TABLE IV-Proportion of doctors (British and Irish graduates; white Anglophone country graduates; other overseas graduates) disappointed with jobs, training, and pay

\begin{tabular}{lccc}
\hline & \multicolumn{3}{c}{ Percentage of doctors disappointed } \\
\cline { 2 - 5 } & $\begin{array}{c}\text { British and Irish } \\
\text { graduates }\end{array}$ & $\begin{array}{c}\text { White Anglophone } \\
\text { graduates }\end{array}$ & $\begin{array}{c}\text { Other overseas } \\
\text { graduates }\end{array}$ \\
\hline $\begin{array}{l}\text { Job opportunities } \\
\text { Study and training }\end{array}$ & 12 & 10 & 33 \\
Pay or holiday & 12 & 7 & 24 \\
\hline
\end{tabular}

and $5 \%$ of white overseas doctors.) But it might be argued that this was appropriate because of their poor English or doubts about the quality of their qualifications. Smith, however, when he adjusted for age, language competence, and qualifications still found a substantial gap in the seniority of overseas and British graduates.

Sixty per cent of British doctors thought that British-qualified doctors were more competent than Asian doctors, and $86 \%$ thought that an overseas doctor would be disfavoured at a job application. About $18 \%$ of British doctors and $18 \%$ of coloured overseas doctors thought that selection boards rejected overseas doctors on racial grounds. Twenty-two per cent of coloured doctors claimed personal experience of racial discrimination when applying for hospital jobs. None of these figures amount to proof of discrimination, but some kind of institutionalised racial discrimination cannot be ruled out. Smith recommended that an investigation into whether selection boards were discriminatory might be made, and he wondered also whether the law should be invoked in cases of suspected discrimination.

\section{How many overseas doctors are stuck?}

Dr Korlipara, the secretary of the Overseas Doctors Association, thinks that there are about 5000 overseas doctors in Britain who do not have career posts and are unlikely to get one in the present highly competitive job market, yet cannot go home. They cannot go home either because they are married to English people, or for political reasons, or because they have been so long in Britain that they feel they belong here. The Overseas Doctors Association is very concerned for these doctors.

But are there really 5000 such doctors? Some calculations can be made from David Smith's figures. In his study only $48 \%$ of overseas doctors working in hospitals aged 45-54 and only $54 \%$ of those over 55 were consultants. Those hospital doctors who are this old and not consultants seem to be stuck: they are unlikely to return home, and they are unlikely to become either consultants or principals in general practice. Seven per cent of those aged 45-54 were still senior house officers. And in Smith's study about $12 \%$ of the overseas-qualified hospital doctors were aged 45 and over. Hence there were about 700 overseas doctors aged over 45 working in junior hospital jobs. Some of the younger overseas doctors, of whom there are many more, may be unable to return home or to get career jobs, but it does seem that the number of overseas doctors who are "stuck" is nearer 1000 than 5000 .

The next article will consider fully the future of these doctors and discuss various proposals for improving the relationship between overseas doctors and the National Health Service.

\section{References}

1 Royal Commission on Medical Education 1965-8. Report. London: HMSO, 1968 (Cmnd 3569).

2 Anonymous. Doctors from overseas. $\mathrm{Br} \operatorname{Med} \mathcal{F} 1969 ; \mathrm{i}: 729-30$.

3 Committee of Inquiry into the Regulation of the Medical Profession. Report. London: HMSO, 1975 (Cmnd 6018).

4 Royal Commission on the National Health Service. Report. London: HMSO, 1979 (Cmnd 7615)

5 Smith DJ. Overseas doctors in the National Health Service. London: Heinemann for the Policy Studies Institute, 1980 (1) 